\title{
Children's literature in the blogosphere
}

\author{
Pat Pledger \\ Director \\ ReadPlus \\ Australia
}

\begin{abstract}
Blogs about children's literature can enhance professional knowledge and provide up to date information as well as giving insights into the writing process. This paper will examine different types of blogs that readers can use to find out about trends, new books, authors, reviews, and student use. It will also examine strategies to increase the value of library homepages with instant up to date news about what's new in the library. The advantages and the limitations of blogs along with factors to consider when creating and subscribing to blogs will also be explored.
\end{abstract}

A weblog can be defined as any web page with content organised according to date. In the United States, 8\% of Internet users keep a blog and 39\% read blogs. 54\% of US bloggers are under the age of 30 and are divided evenly between men and women. (Lenhart, A. \& Fox, S. 2006). Blogs are increasingly being used by librarians as a means of keeping up-to-date with current issues in children's literature and reading about new books. Blogs will appeal to the younger generation that is avid users of the Internet and this technology would be useful in motivating young readers and writers.

\section{The many uses and benefits of blogs}

Weblogs provide simple web publishing space for individuals and are easy to create and maintain with little html knowledge required. New content can be published instantly from any location in the world, which has Internet access. Blogs also have the ability to archive old material, thus giving a webpage a new look. (Fichter, D. 2003). A blog may also be used as a section of a website that can be updated instantly without any fuss. Another advantage is that a blog can be used to filter and organise information from many sites. It is possible for bloggers to collaborate with people around the world and allow readers to make comments about their content and add useful suggestions. Most software is free, so having a blog is a low cost option for a web presence.

Weblogs may be effective in engaging student interest and could be used for reviews, discussion of novels, publishing individual's poems and stories or keeping a reflective journal about books that have been read. Links can be made to podcasts and videocasts and a photo album can also be used and some files stored. Students and teachers can use the weblog as a place to store handouts about books and information about meetings and schedules. All these factors make blogs a helpful tool for giving their creators and readers a headstart in becoming knowledgeable about children's literature. 


\section{Blogs can enhance readers' knowledge of current children's literature and help keep them up to date with trends.}

Many of the blogs authored by librarians and reviewers give diverse views and opinions and the reader can quickly gain the viewpoints of others working in the same field (Swarz, G. 2005). This can be invaluable for a busy school librarian. Instead of searching the web for information, the selection of some well-maintained, high-quality weblogs will save time and add to professional growth by providing current information. It is also possible to retrieve this information for later use.

Blogs like Read Alert (Centre for Youth Literature 2007) from the State Library of Victoria, Achockablog (Thorn, Michael, 2007) and Read Roger, the Horn Book's editor rants and raves (Sutton, Roger. 2007), can be useful additions to professional reading about books and authors. They provide cutting edge news about children's literature, reviews of interesting books to read, lists of starred books and links to shortlists of awards. Blogs also supply the reader with food for thought about different aspects of children's literature. Some issues that have been raised include censorship, reviewing books, and the relevance of authors' web sites. The Misrule blog (Ridge, J. 2005) is a blog for readers who wish to gain information about books and also get to know about the author's perspective on life.

\section{Authors' blogs give insights into personalities, the writing process and the publishing world}

Authors' blogs have the ability to convey instant and often fascinating personal information about writers as well as give insights into the writing process. A reader may not want to read these personal blogs everyday, but they would be a very useful source of information for students doing an author study and for those students who are keen to learn about the writing process. It is interesting to note that Margo Lanagan, author of the award winning short stories White Time, goes to writing retreats. Another example is Scott Westerfeld's blog, which is fascinating not only for those who like his books but to those who are interested in book covers, illustrations and the international nature of book publishing.

The State Library of Victoria (Centre for Youth Literature 2007) uses a blog for the Writer in Residence section of their Inside a dog web site. Authors such as Garth Nix and Markus Zusak have used this blog to give insights into the creative process. Because of its portable nature, the authors in residence have been able to keep the blog up-to-date while travelling abroad. Readers have gained an understanding of how meeting new people and seeing new landscapes have inspired the authors and given them ideas for new novels.

Using blogs to whet the appetite of readers is an interesting publicity ploy. Susan Hill, the British author of The Woman in Black has used her blog to gauge the feelings of her young audience. She published three chapters of a book for 7-10 year olds on her blog and the resulting good publicity and positive comments added to the blog meant that the publisher, Bloomsbury, took an option on the novel.

Linda Lee Lowe (Lowe, 2007) has published a Young Adult novel, Mortal Ghost, in a serialised form on a blog. The reader was able to read a chapter per week over a forty-week period and had the opportunity to listen to a podcast. The book will be available in a pdf format when the serial is finished. Reading a novel in this fashion gives the reader an 
opportunity to reflect on the writing process and to discuss what literary ploys the author needs to maintain continuity. Reading comments from other readers and the author gives insights into the imagery and plot. Awareness of the reading process and the way that individuals read can also be gained from this process.

\section{Blogs that contain book reviews can give readers suggestions for new books and the opportunity for students to write for their peers}

Review blogs are another way to gain information about what's new in the publishing world. Readers can gather a wealth of recommended reading material and blogs may also provide an opportunity for people who are isolated to discuss books in a safe environment. The ReadPlus Review blog (Pledger, P., 2007) aims to inform its audience, librarians and students, about recently published books, while at the same time giving a fresh look to the home page. Chicklish (Chicklish, 2007) is a bright and engaging blog aimed at adolescent girls and gives information, reviews and links about books that would appeal to them.

Using blogs can be a means of engaging student interest and fostering understanding of books and methods of authorship. Research has shown that the main reasons for keeping a blog are creative expression and sharing personal experiences. (Pew, 2006). If a school library uses a blog, students are not only given the opportunity to use technologies that appeal to the age group, but can promote books to their peers. Book Look (Callison, M., 2007) is an excellent example of this. It is a blog where student reviews of books and audio books are advertised. Each is given a star rating and there are links to a podcast of the review. Comments can be made about the review, positively reinforcing the work of the students. One teacher (Ahlness, M., 2007) has used his Sustained Silent Reading time to allow his students to read blogs. Having students write reviews for a library blog and then encouraging them to read other posts and reviews would be a worthwhile activity as they would be not only practising reading skills but gaining writing skills if given the opportunity to comment on the blog entry.

Blogs like Bookin2bookweek (Kuiri, M. 2006) can be set up for a specific occasion like Book Week, allowing students to write reviews about books for that event. Class teachers can also be involved in typing the entries for young students. This type of blog may not be continued after the event but provides a wonderful opportunity for children to publish on an international forum and for their parents and other members of the school community to see their work.

Allowing comments on book review blogs will provide the opportunity to "create a discussion, a place for feedback or provide a sense of community for both the author and his reader as well as serve as a way to get a sense of the number of active readers." (Pew 2006).

\section{Blogs can be used to give instant up-to-date news and promote books and reading}

Blogs can be used to increase the value of library homepages with instant up to date news about new books and events in the library. The aim of the St Joseph County Public Library blog, for example, is to "keep our patrons informed and amused with information about upcoming releases in the worlds of publishing and entertainment, local and Web 
resources as well as news about programs and events throughout the library system. The blog is authored by SJCPL librarians." (Anderson, J., 2005)

An important function of a blog can be to promote books and reading to the library community. Book Bites (Thomson, M., 2006) is the book blog of Patrician Brothers College Blacktown Library. It contains not only reviews by students, but information about events like the Patrician Brothers' Blacktown Readers' Challenge and links to reviews and author websites of books that the students are reading for the competition. Blogs can also tie in the teacher librarian's programming and give teachers and parents the opportunity to become aware of what students are reading outside of the school curriculum. Using blogs can enhance running library literature circles and book groups. Details of books to be read dates and meetings can be given. The Bookworms Reading and Writing About Reading (Bookworms 2007) is a blog from Hunterdon Central Regional High School that features the books which will be read by their book group as well as meeting dates. The Delaney Book Club (Delaney Book Club, 2007). web site contains a blog with entries by students about what they are reading.

It is possible to use a blog as a virtual display to promote new books, celebration of authors and events like St Valentine's Day. A blog is more conversational than a virtual display and the ability to link to other pages can make it a valuable source of information for patrons. The virtual display can also be archived and is accessible for use while a real display will be dismantled. If a book list is compiled, then it can become part of the virtual display, as well as a hand out for clients.

A blog can provide valuable advice about what to read next and to group books under themes. Hunterdon Central Regional High School uses its blog Central Book Nook (Book Nook 2007) to promote reading under themes such as forensic science. It displays book covers and refers the reader to a printable document that could be taken to the shelves when looking for books under that theme. It combines good online and offline strategies to meet the needs of its students. New books are also featured.

\section{Factors to consider when creating a blog}

\section{Purpose of blog}

The creator needs to have firmly in mind the purpose of the blog that is to be created. It may aim to promote books and reading, provide information about new materials, give students the opportunity to review books or to reach a wider audience. If the skills and interests of the librarian are used, then it may be possible to repackage and reuse materials that are already being produced for the library. If the blog is going to require new materials, such as original reviews, then time needs to be set aside to produce it. (Welsh, A. 2007).

\section{Time factor}

Creating a blog can be very time consuming Although the software is free and usually easy to operate, creators of blogs wishing to have current and interesting material will need to spend sufficient time on producing a worthwhile product. A certain level of html expertise is necessary for inserting book covers, graphics and giving the site a professional appearance. 
Time also needs to be set aside not just for updating on a regular basis, but for future development.

\section{Audience}

The creator of a blog needs to have considered whom is the intended audience for the blog and supply appropriate materials for that audience to keep them reading. The blogger needs to remember that a blog may have an audience wider than the one originally designated, and the implications of parents, publisher or an international reading audience should be carefully thought about. A blog can target users who wouldn't usually come through the library door. Means of promoting the blog need to be put into place.

\section{Factors to consider when subscribing to blogs}

Although blogs can be very useful, it is necessary to consider their limitations before deciding what blogs to subscribe to. Avoiding an overload of information is often the most crucial consideration for the user. Reading a blog can be time consuming and it is essential that users decide what they wish to receive from the reading experience and whether it is worth the time. Careful consideration of a blog's content over a period of time will prove its usefulness. Some blogs may be ones that are subscribed to and dipped into for occasional snippets of information.

Another point to consider is that often the information is not in-depth, although links may be made to articles and viewpoints. Material in the blog can also be of a personal nature and the reader must decide if this is what they wish to read. When a number of people are allowed to collaborate in the weblog, privacy and safety can be an issue.

\section{RSS feeds}

Weblogs generate a behind-the-scenes code in a language similar to HTML called XML. This code, usually referred to as a RSS feed (as in "Rich Site Summary" or "Real Simple Syndication"), makes it possible for readers to subscribe to the content that is created on a particular Weblog so they no longer have to visit the blog itself to get it. One useful aggregator or blog collector is Bloglines (Bloglines, 2005). Sites that have been collected are checked on a regular basis and put into a folder to be read at the user's convenience.

An RSS feed on a blog can be an easy way to draw attention to the resources found there. If the resources are good, it may bring some traffic.

Blogging is bringing new voices to the online world (Pew 2006), and is a powerful tool for gaining knowledge about children's books and reading and for finding out what is happening in the publishing world. Students will benefit from being able to use this tool and will gain valuable insights into the reading and writing process. 


\section{References}

Anderson, Joseph (2005). St. Joseph County (IN) Public Library: How Do You Spell "Blog"? Retrieved March, 29, 2007 from http://www.webjunction.org/do/DisplayContent?id=9140

Bloglines, 2005, Trustic Inc. Retrieved March 29, 2007 from http://www.bloglines.com/

Five Weeks to a Social Library. Retrieved March 29, 2007 from http://www.sociallibraries.com/course/node.

Fichter, Darlene (2003) Why and How to Use Blogs to Promote Your Library's Service. Retrieved March 29, 2007 from http://www.infotoday.com/mls/nov03/fichter.shtml

Lenhart, A. \& Fox, S. (2006). Bloggers: A portrait of the Internet's new storytellers. Washington D.C.: Pew Internet and American Life Project. Retrieved March, 292007 from http://www.pewinternet.org/pdfs/PIP\%20Bloggers\%20Report\%20July\%2019\%202006.pdf

Richardson, W 2004, Blogging and RSS — The "What's It?" and "How To" of Powerful New Web Tools for Educators, Information Today, Medford, New Jersey. Retrieved March, 292007 from http://www.infotoday.com/MMSchools/jan04/richardson.shtml

Schwartz, Greg (2005). Blogs for Libraries. Retrieved March 29, 2007 from http://www.webjunction.org/do/DisplayContent?id=767

Welsh, Anne (2007). From writer's block to library blog in Five weeks to a social library. Retrieved March 29, 2007 from http://www.sociallibraries.com/course/node

\section{Blog Resources}

Ahlness, M. (2007). Mark's edtech blog. Retrieved March 29, 2007 from http://www.halcyon.com/arborhts/mahlness/index.htm

Booknook (2007). Hunterdon Central Regional High School Library. Retrieved March 29, 2007 from http://central.hcrhs.k12.nj.us/booknook/

Bookworms (2007). Hunterdon Central Regional High School Library. Retrieved March 29, 2007 from http://central.hcrhs.k12.nj.us/bookworms/

Callison, Matthew. Book Look (2007). Retrieved March 29, 2007 from http://www.booklook.org/

Centre for Youth Literature (2007). Inside a dog: Writer in residence. Melbourne, Victoria: State Library Victoria. Retrieved March 29, 2007 from http://www.insideadog.com.au/links/links.html

Centre for Youth Literature (2005). Read Alert. Melbourne: State Library of Victoria. Retrieved March 29, 2007 from http://www.slv.vic.gov.au/services/education/youthlit/readalert/

Chicklish (2007). Retrieved March 29, 2007 from http://keris.typepad.com/chicklet/

Delaney Book Club (2007). Retrieved March 29, 2007 from http://www.freewebs.com/delanybookclub/

Hill, Susan (2007). Susan Hill blog. Retrieved March 29, 2007 from http://blog.susanhill.com/blog/_archives/2007/3/25/2833432.html

Kuiri, Michael (2006). Bookin2bookweek. Retrieved March 29, 2007 from http://bookin2bookweek2006.blogspot.com/

Lanagan, Margo (2005). Among amid awhile. Retrieved March 29, 2007 from

http://amongamidwhile.blogspot.com/

Lowe, Linda Lee (2007). Mortalghost. Retrieved March 29, 2007 from http://mortalghost.blogspot.com 
Pledger, Patricia (2007) ReadPlus review blog. Retrieved March 29, 2007 from

http://www.readplus.com.au/blog.php

Read Alert (2007). Retrieved March 29, 2007 from

http://www.slv.vic.gov.au/services/education/youthlit/readalert/

Ridge, Judith (2005). Misrule. Retrieved March 29, 2007 from http://www.misrule.com.au/s9y/

Sutton, Roger. (2007). Read Roger, the Horn Book editor's rants and raves. Retrieved March 29, 2007 from http://www.hbook.com/blog/index.html

Thomson, Marita (2005) Book bite Retrieved March 29, 2007 from http://www.bookbite.blogspot.com/.

Thorn, Michael (2007). Achockablog. Retrieved March 29, 2007 from http://www.achuka.co.uk/achockablog/

\section{Author note}

Pat Pledger has been a school library coordinator and English teacher. She is keenly interested in reading and reviews for several Australian journals. Her latest project is ReadPlus, which contains a review blog, book lists and teacher resources. She is co-author with Fran Knight of two collections of senior fiction books. 
Reproduced with permission of the copyright owner. Further reproduction prohibited without permission. 